\section{US safety inspectors barred from making spot checks}

LAST week was a busy one for the Department of Labour's Occupational Safety and Health Administration. On Tuesday, the Supreme Court, in a 5-3 ruling, decided that OSHA inspectors must obtain a warrant before inspecting premises suspected of breaking safety and health regulations. On the same day, it was learnt that President Carter's economic advisers had ordered the agency to delay the publication of regulations covering occupational exposure to cotton dust in the cotton industry on the grounds that the regulations might have an inflationary impact on the economy.

And the General Accounting Office, the investigative branch of the US Congress, published a report claiming that many serious safety hazards are overlooked by OSHA inspectors, and that 25 states which operate their own OSHA-approved health and safety enforcement programmes are doing an inadequate job.

The Supreme Court decision was the result of a case first brought by OSHA in 1975 against a heating and plumbing contractor in Idaho who had barred an OSHA inspector from entering his premises without a warrant, claiming it to be an unconstitutional invasion of privacy. The Supreme Court, to which OSHA had appealed an earlier court ruling, agreed that this was so and that OSHA inspectors required a warrant to carry out inspections. However the court added that it was not necessary for OSHA to meet strict criminal law requirements in order to obtain such a warrant.

Dr Eula Bingham, the head of OSHA, admitted later that the agency might have to alter its inspection procedures, but said that the decision was sufficiently flexible to permit the routine issuance of warrants if employers refused to allow voluntary inspections.

$\mathrm{Mr}$ A. L. Grospiron, however, president of the Oil, Chemical and Atomic Workers and chairman of the AFL-CIO's standing committee on safety and occupational health, said that the decision would give companies time to shut down unsafe operations before inspectors arrived, and that it would "place another roadblock in the way of effective enforcement in the occupational safety and health laws".

The delay in implementing regulations covering exposure to cotton dust, which would affect over 800,000 workers in the cotton industry, follows a report from the council on wage and price stability that OSHA's proposals

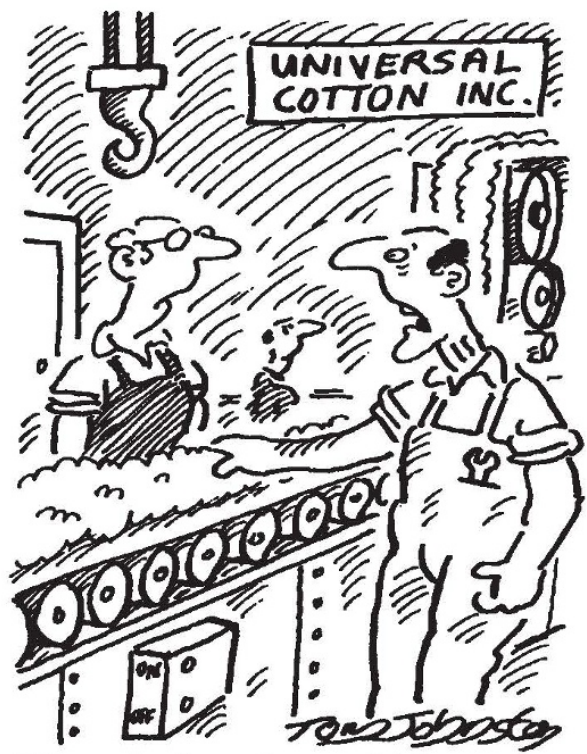

"It's good to know that our sick lungs are helping to fight inflation"

would cost industry $\$ 625$ millions in initial capital expenditure and a further $\$ 200$ million a year.

Although OSHA had previously said that the regulations would be published by 31 May, Charles L. Schultze, chairman of the president's Council of Economic Advisers, has ordered a delay, saying that he wants the proposal to be reviewed for its likely economic impact.

David Dickson

\section{Genetic engineering guidelines: Europe hopeful about collaboration}

INTERNATIONAL accord, if not agreement, emerged from a meeting of the European Science Foundation's genetic engineering liaison committee last week. Despite the presence of a representative of the US National Institutes of Health, which have been expected to relax their containment controls on recombinant DNA research in the next few months, delegates left the meeting with the feeling that no one country was likely to take drastic unilateral action in the near future. Whether the NIH are misleading their European colleagues, or whether the relaxation they are contemplating will in the event be only a minor one, is unclear.

One delegate thought that there had been a "considerable convergence of opinion" at the meeting on how far countries could go towards relaxation. which "would have to be ushered in quite slowly". More scientific evidence and experiments relating to safety would have to be accumulated before there could be any substantial changes in regulations.

Meanwhile in the UK the Health and Safety Executive hope to have their order for compulsory notification of recombinant DNA experiments laid before parliament early this month, and on 15 June the genetic engineering sub-committee of the Select Committee of Science and Technology will meet for its first private briefing with scientists. It will begin to take evidence in early summer, most likely beginning with the Genetic Manipulation Advisory Group. The Department of Education and Science might follow. Then it seems quite possible that a general election will intervene, when the committee would have to be reconstituted.

\section{Scientific cooperation under attack}

SCIENTIFIC cooperation agreements have over the last few years become almost a ritual concomitant of any discussions of dentent. Last week, however, the Seventh British-Soviet Joint Commission found that public endorsement of such agreements can no longer be entirely divorced from the wider issues of the Helsinki accords.

The London meeting commenced only a few days after the sentencing of physicist Yurii Orlov for allegedly slandering the Soviet State. Outside the closing press conference-the sole chance for representatives of the media to meet the Soviet delegation-a determined posse of protesters demanded "No scientific links with Russia". Inside, Academician Vladimir A. Kirillin, Deputy Chairman of the Council, of Ministers of the USSR, and the Rt Hon Edmund Bell, Secretary of State for Trade, exchanged formal compliments and thanks.

Once, however, the meeting was thrown open to the floor, the atmosphere changed. The very first questioner made it quite clear that the Orlov issue outranked any interest in the promising scientific and technological progress noted in the hand-out. "I'm not a man to be scared" claimed Kirillin "so I'm going to give you a rather brief reply". Forty minutes later, under a barrage of incessant questions, he was still replying.

Stripped of its verbiage. Kirillin's answer was simple: the British public is not properly informed about what is going on; otherwise they would realise that Orlov was tried not for his convictions but for breaking the law. In $\mathrm{Mr}$ Dell's opinion, however, the British public has a "rather satisfactory" knowledge of Soviet policy on these matters.

Vera Rich 